Sri Lanka J. Aquat. Sci. 13 (2008): 23-38

\title{
Population dynamics of Hyporhamphus limbatus (Beloniformes, Hemiramphidae) in two lowland reservoirs of Sri Lanka
}

\author{
P.A.D. AJITH KUMARA AND U.S. AMARASINGHE* \\ ${ }^{1}$ National Aquatic Resources Research \& Development Agency, Crow Island, \\ Colombo 15, Sri Lanka \\ ${ }^{2}$ Department of Zoology, University of Kelaniya, Kelaniya 11600, Sri Lanka \\ *Corresponding author (E-mail: zoousa@kln.ac.lk)
}

\begin{abstract}
Although Hyporhamphus limbatus is found in several lowland reservoirs of Sri Lanka, due to gear restrictions imposed through fisheries regulations, this species remains unexploited or under-exploited in spite of having a good consumer preference. Population dynamics ofH. limbatus in two Sri Lankan reservoirs, namely Minneriya and Udawalawe were investigated in the present study. Length frequency data of $H$. limbatus caught in shore seine nets of mesh sizes $1 \mathrm{~mm}, 5 \mathrm{~mm}$ and $7 \mathrm{~mm}$ were analysed using FiSAT software package and the von Bertalanffy growth parameters were estimated for non-seasonalised growth. Asymptotic total length was $155.4 \mathrm{~mm}$ for Minneriya and $156.4 \mathrm{~mm}$ for Udawalawe. Growth constants of $H$. limbatus for Minneriya and Udawalawe were 1.37 and 1.09 year ${ }^{-1}$ respectively. High total mortality rates (4.90 in Minneriya and 3.01 in Udawalawe), which are equivalent to production/biomass ratio indicate that both stocks can withstand heavy fishing. Relative yield-per-recruit $\left(Y^{\prime} / \mathrm{R}\right)$ analyses indicate that at present these stocks are under-exploited and that by increasing size at first capture to about $70 \mathrm{~mm}, \mathrm{Y}^{\prime} / \mathrm{R}$ can be optimized at the exploitation rate of 0.6. The shore seine nets of $5 \mathrm{~mm}$ mesh sizes can be used to exploit H. limbatus in both reservoirs. However, juveniles of exotic cichlids and other non-target species caught in the nets are needed to be released back to reservoirs.
\end{abstract}




\section{Introduction}

Hyporhamphus limbatus (Valencinnes) (Synonyms: Hemiramphus limbatus, Hyporhamphus gaimardi) is originally a marine species (Munro 1955) but there are established population of this species in several lowland freshwater reservoirs of Sri Lanka (Schiemer and Hofer 1983; De Silva 1988; Silva and Davies 1988; Pethiyagoda 1991; Chandrasoma and Wijeyaratne 1990; Piet et al. 1999; Weliange and Amarasinghe 2003). In some Sri Lankan reservoirs such as Mahawilachchiya, Kaudulla, Minneriya and Udawalwe, this species is exploited at subsistence level using small-mesh $(5 \mathrm{~mm}$ stretched mesh) drag nets (Silva and Davies 1988; Chandrasoma and Wijeyaratne 1990). Although this species has a good consumer preference, only sporadic exploitation of $H$. limbatus is evident possibly due to gear restrictions in Sri Lankan reservoirs imposed through fisheries regulations. In the Sri Lankan reservoir fisheries, use of any kind of drag nets or seine nets is not allowed and the minimum permissible mesh size (stretched) in the gillnet fishery is $8.5 \mathrm{~cm}$.

Although information about some biological aspects ofH. limbatus is available (Silva and Davies 1988; Chandrasoma and Wijeyaratne 1990; Weliange and Amarasinghe 2003; Ariyaratne et al. 2008), no studies have been reported on the population dynamics of this species in Sri Lankan reservoirs. Such knowledge will be useful for defining optimal fishing strategies for these fish stocks. This is of particular importance because utilization of biological fish production in Sri Lankan reservoirs is known to be incomplete (Pet et al. 1996). In the present paper, an attempt is made to investigate population dynamics of H. limbatus in two Sri Lankan reservoirs using lengthbased stock assessment methods.

\section{Materials and Methods}

Studies were conducted in Minneriya $\left(8^{\circ} 02^{\prime} \mathrm{N} ; 80^{\circ} 53^{\prime}\right.$ E) and Udawalawe ( $\left.6^{\circ} 27^{\prime} \mathrm{N} ; 80^{\circ} 50^{\prime} \mathrm{E}\right)$, two lowland reservoirs of Sri Lanka. Some physico-chemical and biological characteristics of the two reservoirs are given in Table 1. The most dominant species in the fisheries of the two reservoirs are Oreochromis mossambicus and O. niloticus. In Udawalawe, Labeo dussumieri, L. rohita and Catla catla also form significant proportions of landings especially during the rainy season (Sricharoendham et al. 2008). Although some fishers in these two reservoirs catchH. limbatus using drag nets, which are illegal, collection of length frequency data (LFD) from the landings of fishers was impracticable. This was mainly due to the reason that being an illegal fishing method, fishers do not land their. limbatus catches at the regular landing sites. 
Table 1. Some morphometric, hydrological, physico-chemical and biological parameters of the two reservoirs studies*.

\begin{tabular}{|c|c|c|}
\hline Parameter & Minneriya & Udawalawe \\
\hline Type & Irrigation & Irrigation \\
\hline River basin & Mahaweli & W alawe \\
\hline Y ear of construction & $\begin{array}{l}276 \text { AD } \\
\text { (Renovated in1903) }\end{array}$ & 1969 \\
\hline $\begin{array}{l}\text { Altitude ( } m \text { above mean sea } \\
\text { level) }\end{array}$ & 96.0 & 88.4 \\
\hline Area $\left(\mathrm{km}^{2}\right)$ & 25.5 & 34.1 \\
\hline Mean depth (m) & 5.8 & 7.9 \\
\hline Maximum depth (m) & 13.0 & 20 \\
\hline Volume $\left(\mathrm{x} 10^{6} \mathrm{~m}^{3}\right)$ & 170.2 & 268 \\
\hline Catchment area $\left(\mathrm{km}^{2}\right)$ & 249 & 1,164 \\
\hline Dead storage $\left(\mathrm{x} 10^{6} \mathrm{~m}^{3}\right)$ & 3.2 & 26.26 \\
\hline Shoreline $(\mathrm{km})$ & 60.4 & 53.0 \\
\hline Shoreline development & 2.78 & 4.38 \\
\hline Temperature ${ }^{\circ} \mathrm{C}$ & $26.5-31.5$ & $26.5-29.2$ \\
\hline Conductivity $\left(\mu \mathrm{S} \mathrm{cm}^{-1}\right)$ & $97-203$ & $102-160$ \\
\hline Secchi depth $(\mathrm{cm})$ & $45-280$ & $50-250$ \\
\hline Chl-a $\left(\mu g ~^{-1}\right)$ & $6.0-40.0$ & $5.0-14.0$ \\
\hline
\end{tabular}

*Source: Weliange and Amarasinghe (2007) and Silva et al. (2008).

For collection of LFD, experimental fishing was therefore carried out using shore seine nets of three mesh sizes $(1 \mathrm{~mm}, 5 \mathrm{~mm}$ and $7 \mathrm{~mm})$. The length of the seine net of $1 \mathrm{~mm}$ mesh size was $8.5 \mathrm{~m}$ and the height was $1 \mathrm{~m}$. The length and height of the seine net of $5 \mathrm{~mm}$ mesh size were $25 \mathrm{~m}$ and 1.9 $\mathrm{m}$ respectively. The $7 \mathrm{~mm}$ mesh seine net was of $50 \mathrm{~m}$ in length and $2.3 \mathrm{~m}$ in height. The floats fixed to the head rope and the lead sinkers of the bottom rope facilitated the operation of the nets which was performed by four persons. Experimental fishing for collection of LFD of $H$. limbatus was carried out approximately bimonthly. In Minneriya reservoir, there were 13 fishing trials from August 1998 to January 2001 whereas 12 fishing trials were carried out in Udawalawe reservoir from September 1998 to May 2000. On each field visit, there were 3-4 sampling dates during when 2 to 6 fishing trials were carried out from seine nets of each mesh size in different locations of inshore area of each reservoir, depending on the bottom characteristics and absence of impediments to shore seining. Total length (TL) of each $H$. limbatus caught was measured in situ using a measuring board to the nearest $\mathrm{mm}$. As $H$. limbatus has an elongated lower jaw and an opposite heterocercal caudal fin, TL was measured from the tip of the lower jaw to the edge of the lower lobe of the caudal fin. TL measurements of $H$. limbatus during each 
field visit in each reservoir were pooled and were grouped into $5 \mathrm{~mm}$ class intervals.

LFD were analyzed using FiSA T II (version 1.2.2) software package (Gayanilo et al. 2006) for fitting the von Bertalanffy growth model for nonseasonalized growth described by the following equation.

$$
\mathrm{L}_{\mathrm{t}}=\mathrm{L}_{\infty}\left[1-\mathrm{e}^{-\mathrm{K}\left(\mathrm{t}-\mathrm{t}_{\mathrm{O}}\right)}\right]
$$

where $L_{t}$ is the length of fish at age $t, L_{\infty}$ is the asymptotic length, $K$ is the growth constant and $t_{0}$ is the theoretical age at length zero. As ELEFAN and similar methods of analyzing LFD are known to be effective when one of the two von Bertalanffy parameters, $\mathrm{L}_{\infty}$ or $\mathrm{K}$, is approximated (Basson et al. 1988), $\mathrm{L}_{\infty} \approx \mathrm{L}_{\max }$ where $\mathrm{L}_{\max }=$ maximum length in the catch samples, was assumed as the root value (Gayanilo and Pauly 1997). Using this root value, preliminary estimates of $\mathrm{L}_{\infty}$ and $\mathrm{K}$ were then determined by means of ELEFAN I routine of FiSA T II software. In ELEFAN I, von Bertalanffy growth model is fitted by a non-parametric method where the optimum growth curve that passes through the highest number of peaks in the length frequency samples which are sequentially arranged with time as determined from the goodness of fit value, Rn (Gayanilo and Pauly 1997). Here, restructuring of length frequencies i.e., dividing frequencies of each length class by moving average over five length-classes, followed by their transformation using average adjusted frequency value minus 1 as the denominator, allows the identification of peaks independent of their height.

As the sampling devices were seine nets of $1 \mathrm{~mm}, 5 \mathrm{~mm}$ and $7 \mathrm{~mm}$ mesh sizes, small fish which can escape from the meshes do not represent the population. However, for fitting von Bertalanffy growth model, small size classes of fish in the catch sample are important because they determine the curvature of growth curve. Hence, the following procedure was adopted to correct the LFD for selectivity effects of the sampling gear as proposed by Pauly (1986).

First, using the preliminary estimates of $\mathrm{L}_{\infty}$ and $\mathrm{K}$, total mortality $(\mathrm{Z})$ was calculated from the LFD by the length-converted catch curve method (Pauly 1983a). In this method, the slope of the following linear regression line fitted to the right hand descending part of the catch curve, starting from the second highest data point, gives an estimate of $Z$.

$$
\operatorname{Ln}\left(\mathrm{C}_{\mathrm{i}} / \Delta \mathrm{t}\right)=\mathrm{c}-\mathrm{Zt}_{\mathrm{i}}
$$

where, $\Delta \mathrm{t}=(1 / \mathrm{K}) \ln \left[\left(\mathrm{L}_{\infty}-\mathrm{L}_{\mathrm{i}}\right) /\left(\mathrm{L}_{\infty}-\mathrm{L}_{\mathrm{i}+1}\right)\right]$ and, $\mathrm{L}_{\mathrm{i}}$ and $\mathrm{L}_{\mathrm{i}+1}$ are lower and upper limits of the $i^{\text {th }}$ length class respectively.

Secondly, through the detailed analysis of the ascending part of the length-converted catch curve, probabilities of capture of smaller size classes were determined. Finally, LFD were corrected using these probabilities of capture. These corrected LFD were then used to determine final estimates of the von Bertalanffy growth parameters ( $\mathrm{L}_{\infty}$ and $\mathrm{K}$ ) by means of ELEFAN I routine of FiSA T II software. 
As $\mathrm{L}_{\infty}$ and $\mathrm{K}$ are not species-specific but are inversely proportional, the following growth performance index $\phi^{\prime}$ ), which falls within a narrow range for taxonomically close species (Moreau et al. 1986), was used to compare growth parameters of hemiramphid species in different localities.

$\varphi^{\prime}=\log (\mathrm{K})+2 \log \left(\mathrm{L}_{\infty}\right)$

As $\varphi^{\prime}$ is sensitive to the units of measurement of $\mathrm{L}_{\infty}$ and $\mathrm{K}$ and the expression of $\mathrm{L}_{\infty}$ (i.e., TL, SL or any other measurement), comparable units and expressions of growth parameters were used in calculating $\varphi$ '. The growth data of hemiramphids, as reported in www.fishbase.org, were compared with those of $H$. limbatus in Minneriya and Udawalawe reservoirs using an auximetric plot, i.e., plot of Ln K against Ln Lo (Pauly 1998).

The third parameter of the von Bertalanffy growth model, the theoretical age at length zero ( $\mathrm{b}$ ) was estimated using the following empirical relationship (Pauly 1983b).

$$
\log _{10}\left(-\mathrm{t}_{\mathrm{O}}\right)=-0.3922-0.2752 \log _{10} \mathrm{~L}_{\infty}-1.038 \log _{10} \mathrm{~K}
$$

Using the final estimates of $\mathrm{L}_{\infty_{0}}$ and $\mathrm{K}, \mathrm{Z}$ values were again estimated from the length-converted catch curve method based on the original, uncorrected LFD. Similarly, from the detailed analysis of ascending part of the length-converted catch curve, probabilities of capture in different size classes were determined. From a plot of probabilities of capture against length, length at $50 \%$ retention was estimated which was considered as the length at first capture $\left(\mathrm{L}_{\mathrm{c}}\right)$.

Natural mortality (M) was estimated using the following empirical equation derived by Pauly (1980).

$$
\operatorname{Ln}(\mathrm{M})=-0.0152-0.279 \operatorname{Ln}\left(\mathrm{L}_{\infty}\right)+0.6543 \operatorname{Ln}(\mathrm{K})+0.463 \operatorname{Ln}(\mathrm{T})
$$

In this method, $\mathrm{L}_{\infty}$ was expressed in TL in $\mathrm{cm}, \mathrm{K}$ was on annual basis and $\mathrm{T}$ was in degrees Celsius. Fishing mortality $(F)$ was estimated by subtracting $M$ from $\mathrm{Z}$ and the exploitation rate (E) was estimated as F/Z (Pauly 1983b).

Recruitment patterns of $H$. limbatus in the two reservoirs were determined from the routine implemented in FiSAT II software, which involved backward projection of length frequencies onto time axis based on growth parameters. Relative yield-per-recruit ( $\left.\mathrm{Y}^{\prime} / \mathrm{R}\right)$ analysis was carried out incorporating probabilities of capture (Pauly and Soriano 1986; Gayanilo and Pauly 1997) as determined for the sampling gear. Assuming that H. limbatus is exploited from the drag nets, which have similar selection characteristics, optimal fishing strategies were determined by the $Y^{\prime} / R$ analysis. In order to allow fishers to increase the efficiency of fishing effort, the E value which corresponds to $10 \%$ of the maximum rate of $Y^{\prime} / R$ increase with increasing $E$, defined as $\mathrm{E}_{0.1}$ was determined as an index of assessing status of the fishery (Gayanilo and Pauly 1997). 


\section{Results}

The LFD of $H$. limbatus caught in $1 \mathrm{~mm}, 5 \mathrm{~mm}$ and $7 \mathrm{~mm}$ mesh shore seine nets are shown in Figure 1. A wide range of lengths was recorded when LFD of catches of seine nets of all three mesh sizes were considered. The growth curves of $H$. limbatus in Minneriya and Udawalawe reservoirs superimposed on LFD are shown in Figures $2 \mathrm{a}$ and $3 \mathrm{a}$ respectively. The corresponding $\mathrm{Rn}$ values (Gayanilo and Pauly 1997) in Minneriya and Udawalawe were 0.199 and 0.135 respectively indicating that all the available peaks in the LFD are not explained by the growth curves possibly due to the continuous recruitment. The von Bertalanffy growth parameters of $H$. limbatus in the two reservoirs are given in Table 2. Length-converted catch curves of $H$. limbatus in Minneriya (Figure 2b) and Udawalawe (Figure 3b) showed erratic patterns in the descending arms of the curves, possibly due to non-proportional representation of abundance in the exploited phase by catch samples. The sigmoid selection curves of $H$. limbatus in beach seines in the two reservoirs (Figures $2 \mathrm{c}$ and $3 \mathrm{c}$ respectively for Minneriya and Udawalawe) permitted estimation of $L_{e}$ for both populations and $Y^{\prime} / R$ analysis incorporating probabilities of capture (Pauly and Soriano 1986).

In both reservoirs, $H$. limbatus showed two peak recruitment pulses (Figures $2 \mathrm{~d}$ and $3 \mathrm{~d}$ in Minneriya and Udawalawe respectively). In Minneriya, recruitment pulses in February and August occurred during the dry months whereas in Udawalawe, peak recruitment coincided with rainy seasons in May and November.

The estimated growth performance indices ( $\left.{ }^{\prime}\right)$ of $H$. limbatus in the two reservoirs fall within the range of hemiramphids in different localities (Table 3). Also, from the plot of $\mathrm{Ln} \mathrm{K}$ against $\mathrm{Ln} \mathrm{I}_{\infty}$ in different stocks of hemiramphids as reported in www.fishbase.org (Figure 4) that can be considered as the 'growth space' of the members of this family (Pauly 1998), it is evident that the estimates of $\mathrm{L}_{\infty}$ and $\mathrm{K}$ of $H$. limbatus in the two reservoirs are biologically reasonable.

Y'/R curves of $H$. limbatus as a function of exploitation rate at the present size at first capture for the two reservoirs are shown in Figure 5. Also shown in Figure 5 are the $\mathrm{Y}^{\prime} / \mathrm{R}$ isopleths ofH. limbatus in the two reservoirs. The estimated mortality rates, mean length at 50\% retention, optimal exploitation rate $\left(\mathrm{E}_{\mathrm{opt}}\right)$ and $\mathrm{E}_{0.1}$ are given in Table 4 . The exploitation rates of H. limbatus in Minneriya and Udawalawe reservoirs were 0.46 and 0.25 respectively, indicating that the both stocks are underexploited. In Minneriya, $\mathrm{E}_{0.1}(0.45)$ is more or less similar to the present level of $\mathrm{E}$ indicating a safe exploitation of $H$. limbatus stock in this reservoir. In Udawalawe reservoir on the other hand $\mathrm{E}_{0.1}(0.40)$ is much higher than the present $\mathrm{E}$ so that there is a provision for further intensification of exploitation. As evident from the $Y^{\prime} / R$ isopleths (Figure 5), optimal $\mathrm{L}_{\mathrm{c}}$ of $H$. limbatus in both reservoirs is greater than $70 \mathrm{~mm}$. As such, it is possible to increase the exploitation rate to the level of about 0.6 if the $\mathrm{L}_{\mathrm{c}}$ is increased to about $70 \mathrm{~mm}$. 

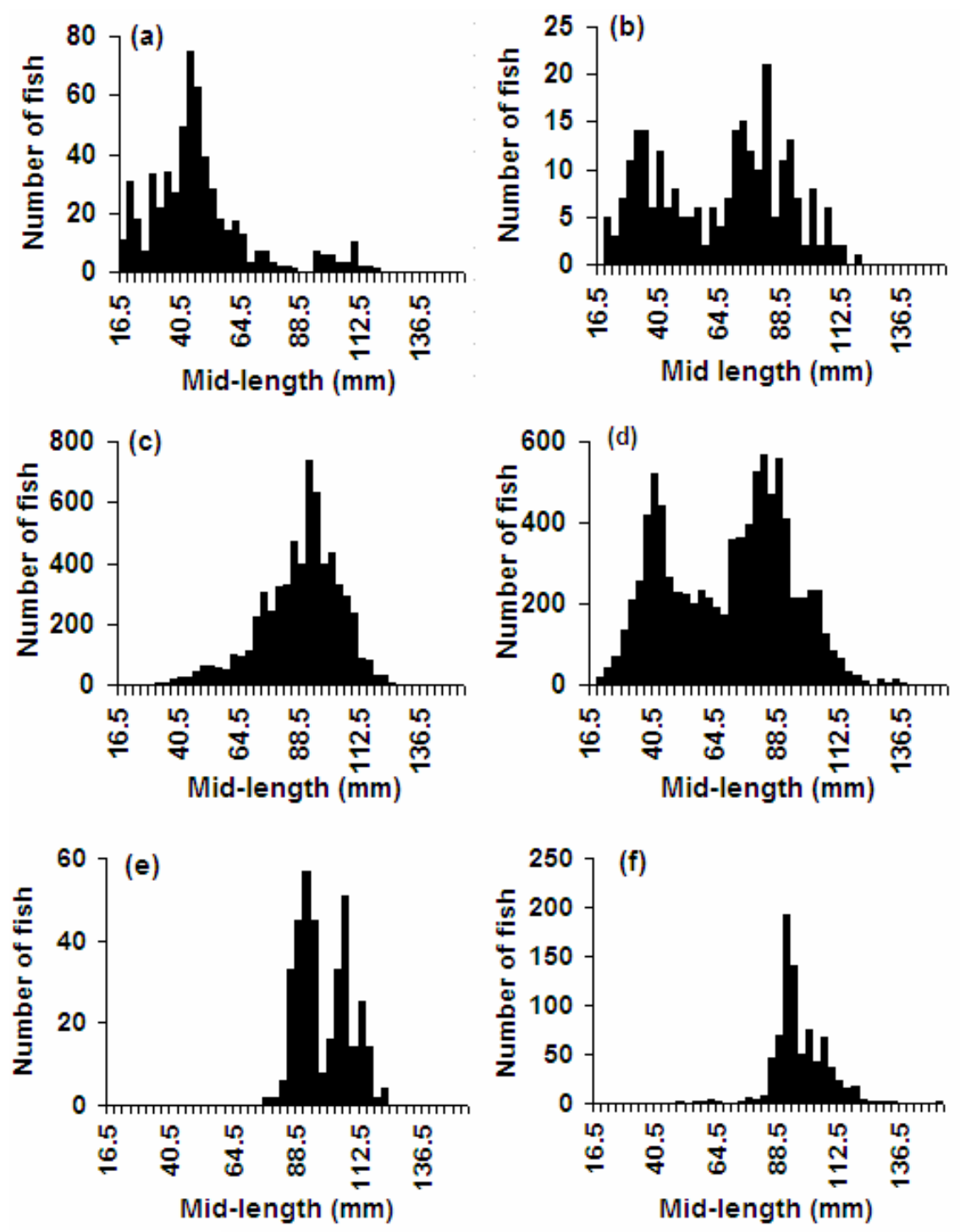

Figure 1. The length frequency data of $H$. limbatus caught in $1 \mathrm{~mm}, 5 \mathrm{~mm}$ and $7 \mathrm{~mm}$ mesh shore seine nets in two reservoirs of Sri Lanka. (a) $1 \mathrm{~mm}$ mesh net in Minneriya; (b) $1 \mathrm{~mm}$ mesh net in Udawalawe; (c); $5 \mathrm{~mm}$ mesh net in Minneriya; (d) $5 \mathrm{~mm}$ mesh net in Udawalawe; (e) $7 \mathrm{~mm}$ mesh net in Minneriya; (f) $7 \mathrm{~mm}$ mesh net in Udawalawe. 
(a)

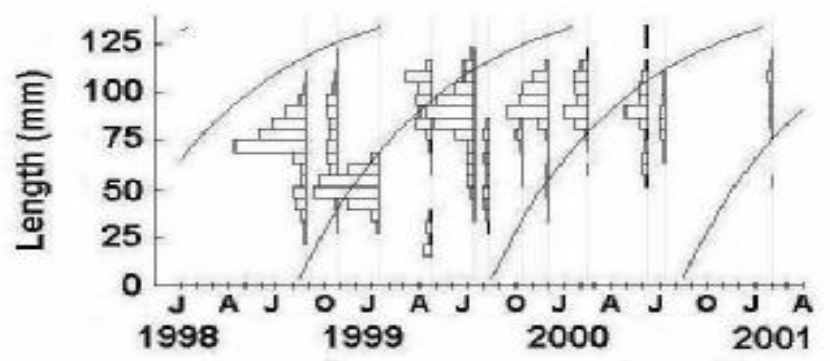

(b)

(c)
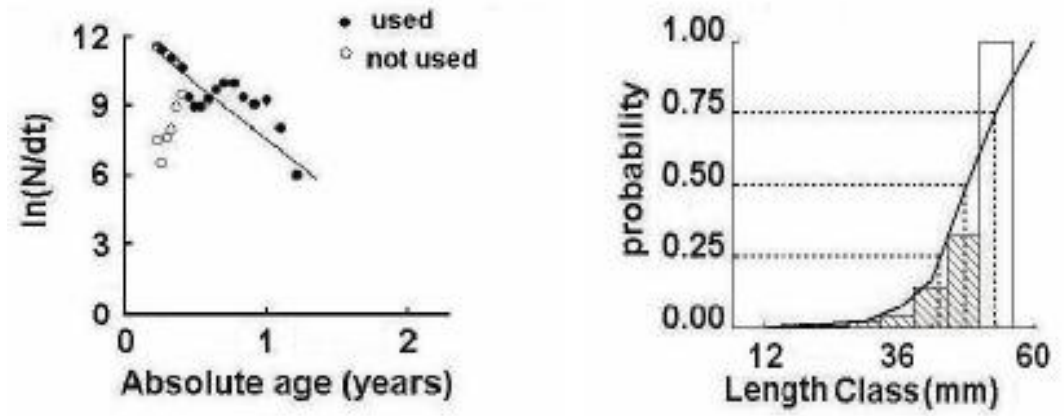

(d)

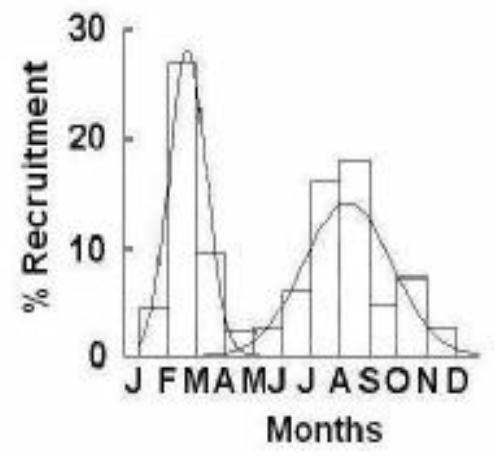

Figure 2. (a) The growth curves superimposed on length frequency data, (b) length-converted catch curve, (c) selection curve and (d) recruitment pattern of $H$. limbatus in Minneriya reservoir. 
(a)

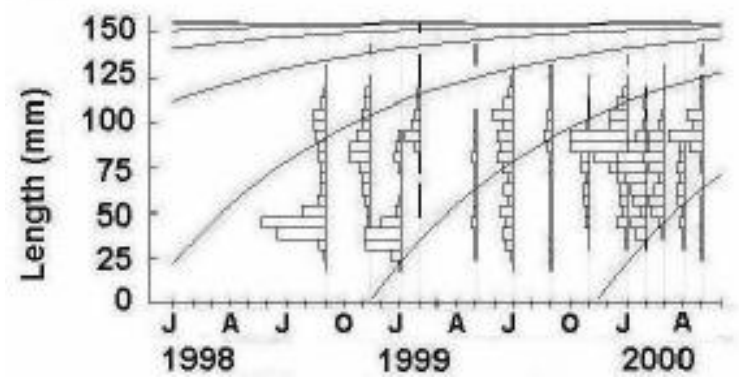

(b)

(c)
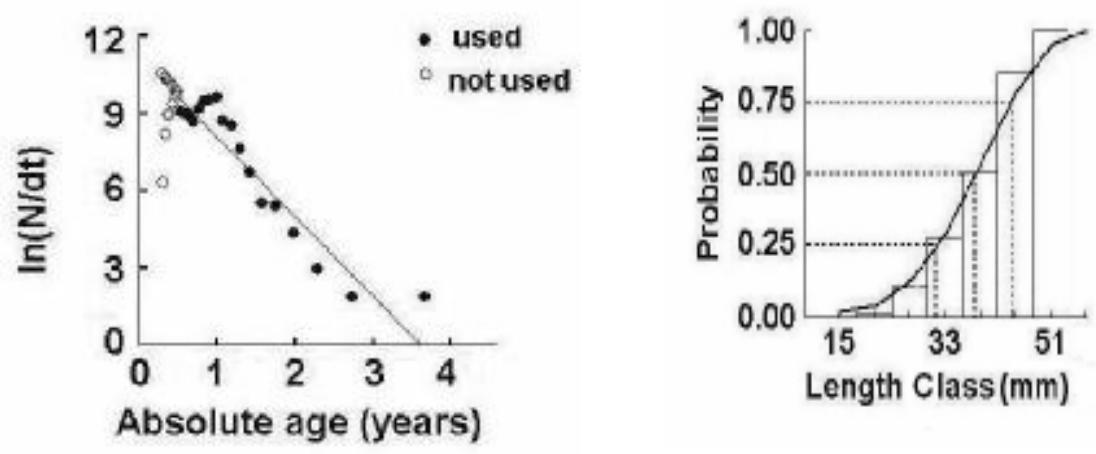

(d)

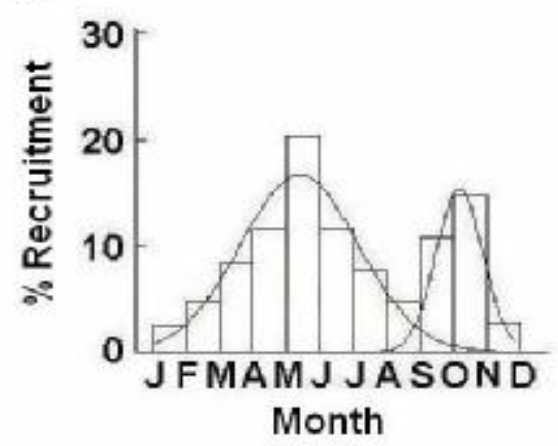

Figure 3. (a) The growth curves superimposed on length frequency data, (b) length-converted catch curve, (c) selection curve and (d) recruitment pattern of $H$. limbatus in Udawalawe reservoir . 
Table 3. The growth performance indices ( $\left(^{\prime}\right)$ of $H$. limbatus in Minneriya and Udawalawe reservoirs. For comparison, mean and range of $\varphi$ ' values of 13 populations of the family Hemiramphidae are also given. Here, $\varphi$ ' was estimated using asymptotic total length in $\mathrm{mm}$ and growth constant on annual basis.

\begin{tabular}{lll}
\hline Species/Locality & $\boldsymbol{\varphi}^{\prime}$ & Authority \\
\hline H. limbatus & 4.52 & \\
Minneriya & 4.43 & Present study \\
Udawalawe & Present study \\
Hemiramphidae(13 genera) & & \\
Various localities & $4.70(3.86-5.40$ range $)$ & www.fishbase.org \\
\hline
\end{tabular}

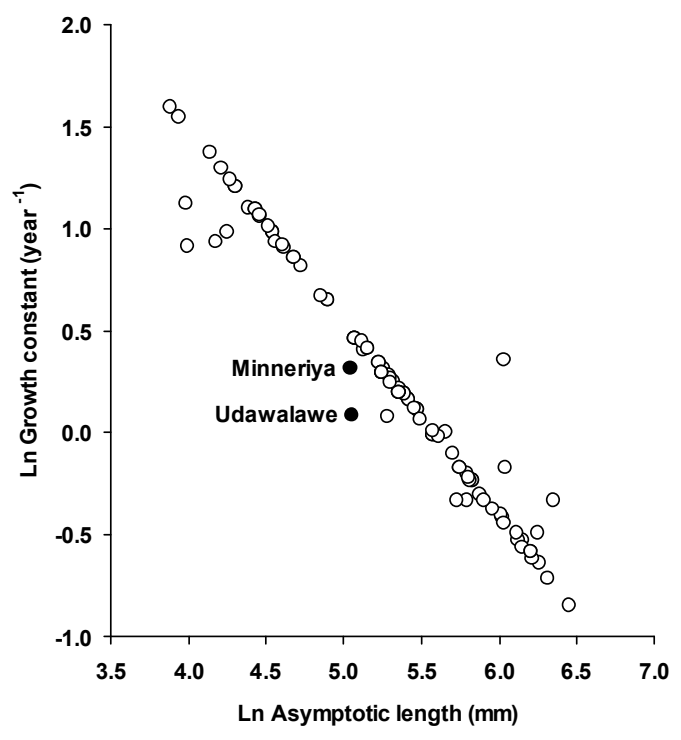

Figure 4. The plot of $\mathrm{Ln} \mathrm{L}_{\infty}$ against $\mathrm{Ln} \mathrm{K}$ in 95 populations of hemiramphids, as reported in www.fishbase.org and the two populations ofH. limbatus in the present study. The black dots represent H. limbatus in Minneriya and Udawalawe reservoirs.

\section{Discussion}

Fishes of the family Hemiramphidae are widely distributed throughout the world and are exploited by commercial and recreational fisheries in many countries (Collete 1974; Sokolovsky and Sokolovskaya 1999; McBride and Thurman 2003; www.fishbase.org). In several lowland reservoirs of Sri Lanka, H. limbatus is found in abundance (Schiemer and Hofer 1983; De Silva 1988; Silva and Davies 1988; Pethiyagoda 1991; Piet et al. 1999). 
Although this species is exploited in small-scale in some reservoirs, as a whole this species remains unexploited or under-exploited due to mesh regulations and gear restrictions in Sri Lankan reservoirs. The importance of the study of population dynamics of $H$. limbatus is two-fold. First, the reservoir fishery of the country is almost entirely dependent on the exotic cichlid species (O. mossambicus and O. niloticus) so that diversification of the fishery is necessary for more complete utilization of biological fish production, as suggested by Pet et al. (1996). Secondly, to understand the trophic interactions in reservoir fish communities where size-selective zooplanktivorous fish species such as $H$. limbatus are present, investigation of population dynamics of zooplanktivorous fish species is imperative H. limbatus is predominantly a zooplankton feeder (Weliange and Amarasinghe 2003) and is reported to be mainly selecting the medium and larger-sized cladocerans, which are slow swimmers, and the large adult insects (Ariyaratne et al. 2008). According to the trophic cascade hypothesis (i.e., the control of zooplankton by size-selective zooplanktivorous fish) zooplanktivorous fish affect the structure of the zooplankton community and in turn, influence the phytoplankton assemblage, primary production and nutrient turnover rates (McQueen et al., 1986; Carpenter et al., 1987; Carpenter and Kitchell, 1993).

Table 4. Total mortality (Z), natural mortality (M), fishing mortality (F), exploitation rates and mean sizes at first capture $\left(\mathrm{L}_{c}\right)$ of $H$. limbatus in Minneriya and Udawalawe reservoirs. Optimal exploitation rates $\left(\mathrm{F}_{\mathrm{ept}}\right)$ and $E_{0.1}$ (see text for definition) at the present levels of $\mathrm{I}_{e}$ are also given here. $\mathrm{E}_{\max }-$ Exploitation rate corresponding to maximum $\mathrm{Y}^{\prime} / \mathrm{R} ; \mathrm{I}_{\mathrm{e}}(\max )-\mathrm{L}_{\mathrm{c}}$ corresponding to maximum $Y^{\prime} / R$.; For other abbreviations, see text.

\begin{tabular}{lll}
\hline Parameter & Minneriya & Udawalawe \\
\hline$Z\left(\right.$ year $\left.^{-1}\right)$ & 4.90 & 3.01 \\
$M\left(\right.$ year $\left.^{-1}\right)$ & 2.63 & 2.26 \\
$F\left(\right.$ year $\left.^{-1}\right)$ & 2.27 & 0.75 \\
$\mathrm{E}$ & 0.46 & 0.25 \\
$\mathrm{~L}_{\mathrm{c}}(\mathrm{mm})$ & 48.2 & 37.9 \\
$\mathrm{E}_{\text {opt }}\left(\right.$ at the present $\left.\mathrm{L}_{\mathrm{c}}\right)$ & 0.54 & 0.48 \\
$\mathrm{E}_{0.1}\left(\right.$ at the present $\left.\mathrm{L}_{\mathrm{c}}\right)$ & 0.45 & 0.40 \\
$\mathrm{E}_{\max }$ & 0.62 & 0.60 \\
$\mathrm{~L}_{\mathrm{c}(\max )}(\mathrm{mm})$ & 69.9 & 68.8 \\
\hline
\end{tabular}

The present analysis has shown that $H$. limbatus in Minneriya and Udawalawe reservoirs can be exploited using shore seine nets of $1 \mathrm{~mm}, 5 \mathrm{~mm}$ and $7 \mathrm{~mm}$ mesh sizes. However, it must be noted that as there is a danger of catching juveniles of exotic cichlids (i.e.,O. mossambicus and O. niloticus) in these shore seine nets, exploitation of $H$. limbatus using shore seines should be carefully monitored to minimize mortality of cichlid juveniles. A $\$$. 
limbatus caught in seine nets can be easily sorted while keeping the net in water, juvenile cichlids and other non-target species that are caught can be released back to the reservoir. As $\mathrm{I}_{\infty}$ and $\mathrm{K}$ are not species-specific parameters, comparison of growth must be taken as a multivariate problem in which both $\mathrm{L}_{\infty}$ and $\mathrm{K}$ can be simultaneously considered. In this context, the growth performance index ( $\varphi$ '; Moreau et al. 1986) is suitable for comparison of overall growth performance of different stocks. Thex' value is shown to be more or less constant for a family for a similar taxon (Moreau et al. 1986). With the present estimates of $\mathrm{L}_{\infty}$ and $\mathrm{K}$ for $H$. limbatus, $\varphi$ ' was 4.52 in Minneriya and 4.43 in Udawalawe. These estimates are in agreement with the estimates of $\varphi^{\prime}$ of hemiramphids as reported in www.fishbase.org. Here, it must be noted that for the purpose of comparison, all $\varphi^{\prime}$ values were estimated using $\mathrm{L}_{\infty}$ as total length in $\mathrm{mm}$ and $\mathrm{K}$ on annual basis.

(a)

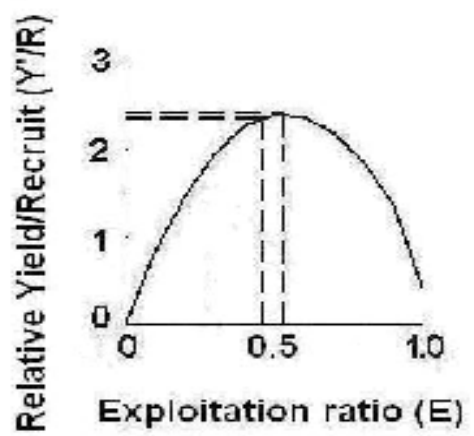

(b)

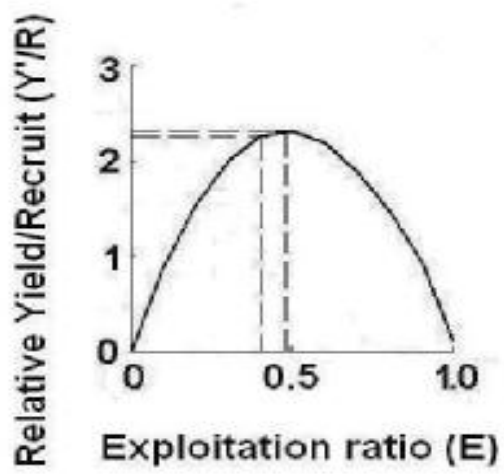

(c)

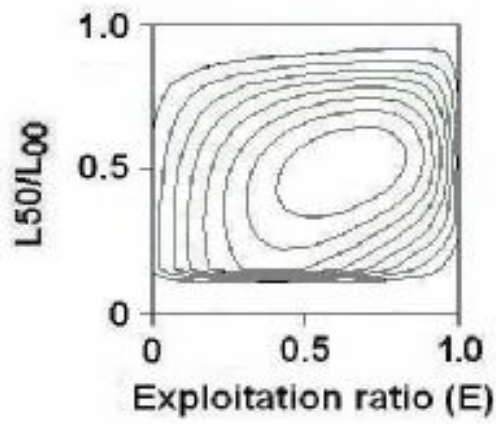

(d)

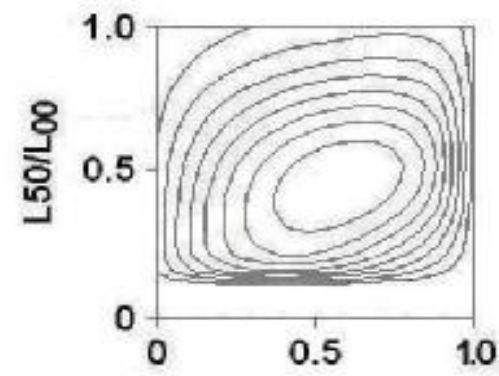

Exploitation ratio (E)

Figure 5. Y'/R curves of $H$. limbatus as a function of exploitation rate at the present size at first capture for (a) Minneriya and (b) Udawalawe and the Y'/R isopleths of $H$. limbatus for (c) Minneriya and (d) Udawalawe. 
Although, erratic patterns in the descending arms of the lengthconverted catch curves (Figures $2 \mathrm{~b}$ and $3 \mathrm{~b}$ ) perhaps indicate non-proportional representation of abundance in the exploited phase by catch samples, a wide range of age classes was considered in estimating $Z$. As such, the $Z$ estimates in the present analysis can be considered reasonably accurate. The $Z$ values of both stocks are considerably high (Table 4). Under steady-state assumptions, $\mathrm{Z}$ is known to be equivalent to production/biomass ratio $(\mathrm{P} / \mathrm{B})$ or turnover rate (Allen 1971). Therefore, it appears that both stocks can withstand heavy fishing. As there are two peak recruitment pulses in both stocks, it can also be expected that the stocks are capable of showing resilience to changing environmental conditions.

In both reservoirs, exploitation rates of $H$. limbatus were below 0.5 suggesting that the fish stocks are lightly exploited. In Minneriya reservoir however, more fishers are engaged in H. limbatus fishing than in Udawalawe reservoir. As there are no submerged decaying tree stumps in Minneriya reservoir in contrary to Udawalawe, drag nets and shore seine nets can be conveniently used in Minneriya reservoir. These differences in fishing intensities are also reflected by exploitation rates of $H$. limbatus in the two reservoirs. In Minneriya, exploitation rate was much higher (0.46) than in Udawalawe $(\mathrm{E}=0.25)$.

The relative yield-per-recruit $\left(Y^{\prime} / \mathrm{R}\right)$ analyses performed here were based on the overall selection patterns of the three seine nets. Based on the assumption that these three seine nets represent the small-scale fisheries of $I$.

limbatus in the two reservoirs, $\mathrm{E}_{0.1}$ in Minneriya reservoir was found to be more or less similar to the present level of exploitation. In Udawalawe reservoir, $E_{0.1}$ was much higher than the present $E$. The $Y^{\prime} / R$ isopleths indicate that the $\mathrm{Y}^{\prime} / \mathrm{R}$ can be optimized in both reservoirs at the exploitation rate of 0.6 if the $\mathrm{L}_{\mathrm{c}}$ is increased to over $70 \mathrm{~mm}$. As most of the under-sized $(<70 \mathrm{~mm}) \mathrm{H}$. limbatus were caught in $1 \mathrm{~mm}$ mesh seine net during the present study (Figure 1), use of seine nets with mesh size $5 \mathrm{~mm}$ and $7 \mathrm{~mm}$ is advocated.

\section{Acknowledgements}

This study was carried out as part of a research project funded by European Union INCO-DC Programme Project Number: IC18-CT-0190. We are thankful to Drs W.S. Weliange and C. Nissanka and Messrs M.G. Ariyaratne and R.P.P.K. Jayasinghe for their assistance in shore seining.

\section{References}

Allen, K.R. 1971.

Relationship between production and biomass. Journal of the Fisheries Research Board of Canada 28: 1573-1581. 
Ariyaratne, M.G., P.B. Amarasinghe, N.C. Lopez, M. Kakkaew \& J. Vijverberg, 2008.

Selective feeding of five species of small zooplanktivorous pelagic fish in South-east Asian reservoirs (Sri Lanka, Thailand) and Lake Taal (Philippines). In: Aquatic Ecosystems and Development: Comparative Asian Perspectives (F. Schiemer, D. Simon, U.S. Amarasinghe and J. Moreau eds). pp. 235-248. Biology of Inland Waters, Backhuys Publishers, Leiden, The Netherlands.

Basson, M., A.A. Rossenberg \& J.R. Beddington 1988.

The accuracy and reliability of two new methods for estimating growth parameters from length frequency data. Journal du Conseil. Conseil International Exploration de la Mer 44: 277-285.

Carpenter, S.R. \& J.F. Kitchell 1993.

The Trophic Cascade in Lakes. Cambridge University Press, Cambridge: $385 \mathrm{p}$.

Carpenter, S.R., J.F.Kitchell, J.R. Hodgson, P.A. Cochran, J.J. Elser, M.M. Elser, D.M. Lodge, D. Kretchmer, X. He \& C.N. von Ende 1987.

Regulation of lake primary productivity by food web structure. Ecology 68(6): 1863-1876.

Chandrasoma, J. \& M.J.S. Wijeyaratne 1990.

Some aspects of the biology of Hyporhampus gaimardi in Uda Walawe reservoir, a man made lake in Sri Lanka. In: The Second Asian Fisheries Forum (R. Hirano and I. Hanyu eds). pp. 569-572.

Asian Fisheries Society, Manila, Philippines.

Collette, B.B. 1974.

The garfishes (Hemiramphidae) of Australia and New Zealand.

Records of the Australian Museum 29: 11-105.

De Silva, S.S. 1988.

Reservoirs of Sri Lanka and Their Fisheries. FAO Fisheries

Technical Paper 298: 128 p.

Gayanilo, F.C. Jr. \& D. Pauly 1997.

FAO/ICLARM Stock Assessment Tools (FiSA T). Reference Manual.

FAO Computerized Information Series (Fisheries), No. 8. FAO, Rome. 262 p.

Gayanilo F.C. Jr., P. Sparre \& D. Pauly 2006.

The FAO-ICLARM Stock Assessment Tools II Revised version, User's guide. ftp://ftp.fao.org/docrep/fao/009/y5997e/y5997e00.pdf 7, $124 \mathrm{pp}$.

McBride, R.S. \& P.E. Thurman 2003.

Reproductive biology of Hemiramphus brasiliensis and H. balao

(Hemiramphidae): maturation, spawning frequency, and fecundity. Biological Bulletin 204: 57-67.

McQueen, D.J., J.R. Post \& E.L. Mills 1986.

Trophic relationships in freshwater pelagic ecosystems. Canadian

Journal of Fisheries and Aquatic Sciences 43: 1571-1581.

Moreau J., C. Bambino \& D. Pauly 1986. 
Indices of overall growth performance of 100 tilapia (Cichlidae) populations. In: The First Asian Fisheries Forum (J.L. Maclean, L.B. Dizon and L.V. Hosillos eds). pp. 201-206. Asian Fisheries Society, Manila, Philippines.

Munro, I.S.R. 1955.

The Marine and Freshwater Fishes of Ceylon. Department of External Affairs, Canberra, Australia. 346 pp.

Pauly, D. 1980.

On the interrelationship between natural mortality, growth parameters and the mean environmental temperature in 175 fish stocks. Journal du Conseil. Conseil International Exploration de la Mer 39(3): 175-192.

Pauly, D. 1983a.

Length-converted catch curves: A powerful tool for fisheries research in the tropics (Part I). Fishbyte 1(2): 9-13.

Pauly, D. 1983 b.

Some Simple Methods for Assessment of Tropical Fish Stocks. FAO Fisheries Technical Paper 234: $52 \mathrm{p}$.

Pauly, D. 1986.

On improving operation and use of the ELEFAN programs. Part IIII. Correcting length-frequency data for the effects of gear selection and/or incomplete recruitment. Fishbyte 4(2): 11-13.

Pauly, D. 1998.

Tropical fishes: patterns and propensities. Journal of Fish Biology 53 (Supplement A): 1-17.

Pauly D. \& M.L. Soriano 1986.

Some practical extensions to the Beverton and Holt's relative yield per recruit model. In: The First Asian Fisheries Forum (J.L. Maclean, L.B. Dizon and L.V. Hosillos eds). pp. 491-495. Asian Fisheries Society, Manila, The Philippines.

Pethiyagoda, R. 1991.

Freshwater Fishes of Sri Lanka. Wildlife Heritage Trust of Sri Lanka, Colombo. $362 \mathrm{p}$.

Pet, J.S., G.J.M. Gevers, W.L.T. van Densen \& J. Vijverberg 1996.

Management options for a more complete utilization of the biological fish production in Sri Lankan reservoirs. Ecology of Freshwater Fish 4: $1-14$.

Piet, G.J., J. Vijverberg \& W.L.T. van Densen 1999.

Foodweb structure of a Sri Lankan reservoir. In: Fish and fisheries of lakes and reservoirs in Southeast Asia and Africa (W.L.T. van Densen and M.J. Morris eds). pp. 187-205. Westbury Publishing, Otley, U.K.

Schiemer, F. \& R. Hofer 1983.

A contribution to the ecology of the fish fauna of the Parakrama Samudra Reservoir. In: Limnology of Parakrama Samudra, Sri Lanka: A Case Study of an Ancient Man-made Lake in the Tropics 
(F. Schiemer ed.). pp. 135-164. Developments in Hydrobiology 12, Dr. W. Junk Publishers, The Hague, The Netherlands.

Silva, E.I.L. \& R.W . Davies 1988.

Notes on the biology of Hemiramphus limbatus (Hemiramphidae:

Pisces) in Sri Lanka. Tropical Freshwater Biology 1: 42-49.

Silva, E.I.L., D. Simon \& F. Schiemer, 2008.

Catchment characteristics, hydrology, limnology and socio-economic features of three reservoirs in Sri Lanka. In: Aquatic Ecosystems and Development: Comparative Asian Perspectives (F. Schiemer, D. Simon, U.S. Amarasinghe and J. Moreau eds). pp. 20-43.Biology of Inland Waters, Backhuys Publishers, Leiden, The Netherlands.

Sokolovsky, A.S. \& T.G. Sokolovskaya 1999.

Some aspects of biology of the Japanese halfbeak Hyporhamphus sajori from Peter the Great Bay, Sea of Japan. Russian Journal of Marine Biology 25: 426-430.

Sricharoendham, B., U.S. Amarasinghe, R.P.P.K. Jayasinghe \& S.M. Aypa, 2008.

Status of the capture fisheries in four Asian reservoirs and a volcanic lake. In: Aquatic Ecosystems and Development: Comparative Asian Perspectives (F. Schiemer, D. Simon, U.S. Amarasinghe and J. Moreau eds). pp. 265-284. Biology of Inland Waters, Backhuys Publishers, Leiden, The Netherlands.

W eliange W.S. \& U.S. Amarasinghe 2003.

Seasonality in dietary shifts in size-structured freshwater fish assemblages in three reservoirs of Sri Lanka. Environmental Biology of Fishes 68(3): 269-282.

W eliange, W.S. \& U.S. Amarasinghe 2007.

Relationship between body shape and food habits of fish from three reservoirs of Sri Lanka. Asian Fisheries Science 20: 257-270. 